\title{
Bilateral Panuveitis at Etanercept Initiation for Juvenile Idiopathic Arthritis
}

\author{
Kaouther Ben Abdelghani ${ }^{a}$, Marwa Slouma ${ }^{a}$, Rym Hajri ${ }^{b}$, Leila Souabni ${ }^{a}$, Leith Zakraoui ${ }^{a}$ \\ ${ }^{a}$ Rheumatology Department, Mongi Slim Hospital, La Marsa, Tunis University, El Manar, Tunisia \\ ${ }^{\mathrm{b}}$ Rheumatologist, private practice, Medical Office, El Manar, Tunisia
}

\begin{abstract}
Introduction: Uveitis is a well-known extra-rheumatological manifestation of juvenile idiopathic arthritis (JIA). Tumour necrosis factor (TNF) has been used to treat uveitis associated with inflammatory diseases. A new-onset uveitis under anti-TNF therapy is uncommon.

Case presentation: A 12-year-old male, affected since the age of 6 years, by a severe form of polyarticular JIA. When etanercept was started, he presented panuveitis bilaterally, so we switched to infliximab with good response.
\end{abstract}

Conclusions: The TNF-soluble receptor could be considered as a possible promoter in inducing endogenous new-onset uveitis in JIA.

Keywords: Anti-TNF therapy, etanercept, juvenile idiopathic arthritis, paradoxical effect, uveitis

Received: $20 / 12 / 2013$

Accepted: $12 / 02 / 2014$

Published: $12 / 03 / 2014$

How to cite this article: Ben Abdelghani K, Slouma M, Hajri R, Souabni L, Zakraoui L. Bilateral Panuveitis at Etanercept Initiation for Juvenile Idiopathic Arthritis, EJCRIM 2014;1:doi: 10.12890/2014_36

Conflicts of Interests: The authors declare that they have no conflicts of interest in this research. 


\section{Introduction}

Juvenile idiopathic arthritis (JIA) is the most common rheumatic disease in children. Uveitis is a well-known extra-rheumatological manifestation of JIA which may lead to severe functional impairment. Tumour necrosis factor (TNF)-alpha blocking agents are increasingly used to treat children with JIA refractory to conventional therapy. Most reports have demonstrated resolution of refractory uveitis under anti-TNF $\alpha$. However, cases of new-onset uveitis under anti-TNF $\alpha$ therapy are rarely reported.

We report herein a new case of paradoxical new onset of uveitis occurring under etanercept treatment in a patient with JIA.

\section{Case Report}

A 6-year-old male child with no significant past medical or family history presented with progressive polyarthralgia and morning stiffness. Physical examination revealed bilateral arthritis of the wrists, proximal interphalangeal joint, knees and ankles. Laboratory findings showed an increase in C-reactive protein (CRP) level and erythrocyte sedimentation rate (ESR). The rheumatoid factor and antinuclear antibodies (ANA) titres were negative. Knee joint X-ray showed soft tissue swelling and wrist joint X-ray showed osteoporotic changes in the epiphysis of the lower end of radius and ulna. Ophthalmological exam was normal. A diagnosis of seronegative polyarticular JIA was established. Methotrexate treatment ( $10 \mathrm{mg} / \mathrm{m} 2$ weekly) was conducted, leading to complete resolution of articular manifestations. After 6 years of clinical remission under methotrexate, a severe arthritis flare occurred. His joint disease was active as shown by DAS 28 at 5.1, while ophthalmologic examination with slit lamp did not show any signs of uveitis. Laboratory findings again showed increased ESR and CRP levels. Etanercept was administered subcutaneously at $0.4 \mathrm{mg} / \mathrm{kg}$ twice weekly and methotrexate was continued. Two weeks after the first injection, and for the first time during his longstanding disease, he presented with painful red eyes and photophobia. Ophthalmologic examination revealed anterior and posterior chamber inflammation of the two eyes. He was treated with oral steroids and beta-blocker ophthalmic drops. Etanercept was suspended and infliximab was started, with no side effects. There was a rapid decrease in his ocular inflammation and improvement in his eye disease. After 20 months, arthritis was stable and complete remission of uveitis was obtained.

\section{Discussion}

JIA is the most common cause of chronic anterior uveitis in childhood. Uveitis is strongly associated with the oligoarticular and seronegative polyarticular subgroups or the presence of ANA. Uveitis in JIA can worsen over time, with many sight-threatening complications, such as cataracts, keratopathies, synechiae and glaucoma. Posterior segment involvement in JIA is rare. This patient had no prior history of uveitis with regular ophthalmological control. 
Studies have shown that etanercept is associated with a risk of new-onset uveitis and uveitis flares in JIA patients. We are aware of only 13 cases of new-onset uveitis in JIA under TNF blockers, presented in Table 1.

\begin{tabular}{|c|c|c|c|c|c|c|c|c|c|}
\hline $\begin{array}{l}\text { Author and } \\
\text { references }\end{array}$ & Gender & $\begin{array}{l}\text { Age } \\
\text { [years] }\end{array}$ & JA subgroup & $\begin{array}{l}\text { Age at } \\
\text { the } \\
\text { onset of } \\
\text { A.l }\end{array}$ & $\begin{array}{l}\text { Type of } \\
\text { TNF } \\
\text { blockers }\end{array}$ & $\begin{array}{l}\text { Interval } \\
\text { between TNF- } \\
\text { blocker } \\
\text { initiation and } \\
\text { the onset of } \\
\text { uveitis } \\
\text { (months) }\end{array}$ & $\begin{array}{l}\text { Type of } \\
\text { uveitis }\end{array}$ & $\begin{array}{l}\text { Treatment of } \\
\text { uveitis }\end{array}$ & $\begin{array}{l}\text { Modification } \\
\text { of TNF } \\
\text { blockers }\end{array}$ \\
\hline $\begin{array}{l}\text { V. } \\
\text { Kakkassery } \\
\text { et al. [1] }\end{array}$ & $\begin{array}{l}\text { F } \\
\text { NS } \\
\text { NS }\end{array}$ & $\begin{array}{l}44 \\
24 \\
16\end{array}$ & $\begin{array}{l}\text { NS } \\
\text { NS } \\
\text { NS }\end{array}$ & $\begin{array}{l}14 \\
15 \\
9\end{array}$ & $\begin{array}{l}\text { Etanercept } \\
\text { Etanercept } \\
\text { Etanercept }\end{array}$ & $\begin{array}{l}6 \\
12 \\
24\end{array}$ & $\begin{array}{l}\text { Posterior } \\
\text { uveitis } \\
\text { Anterior } \\
\text { uveitis } \\
\text { Anterior } \\
\text { uveitis }\end{array}$ & $\begin{array}{l}\text { Oral } \\
\text { corticosteroid } \\
\text { Topical } \\
\text { corticosteroid } \\
\text { Topical } \\
\text { corticosteroid }\end{array}$ & $\begin{array}{l}\text { Switch to } \\
\text { infliximab } \\
\text { Stop } \\
\text { Switch to } \\
\text { infliximab }\end{array}$ \\
\hline $\begin{array}{l}\text { O. } \\
\text { Kaipiainen- } \\
\text { Seppănen et } \\
\text { al. [2] }\end{array}$ & $F$ & 31 & Juvenile SA & 10 & Etanercept & 8 & $\begin{array}{l}\text { Anterior } \\
\text { uveitis }\end{array}$ & $\begin{array}{l}\text { Topical } \\
\text { corticosteroid }\end{array}$ & $\begin{array}{l}\text { Switch to } \\
\text { infliximab }\end{array}$ \\
\hline $\begin{array}{l}\text { E. Martin- } \\
\text { Mola et al. } \\
\text { [3] }\end{array}$ & $\begin{array}{l}\text { NS } \\
\text { NS }\end{array}$ & $\begin{array}{l}\text { NS } \\
\text { NS }\end{array}$ & $\begin{array}{l}\text { Juvenile SA } \\
\text { Juvenile SA }\end{array}$ & $\begin{array}{l}\text { NS } \\
\text { NS }\end{array}$ & $\begin{array}{l}\text { Etanercept } \\
\text { Etanercept }\end{array}$ & $\begin{array}{l}\text { NS } \\
\text { NS }\end{array}$ & $\begin{array}{l}\text { Anterior } \\
\text { uveitis } \\
\text { Anterior } \\
\text { uveitis }\end{array}$ & $\begin{array}{l}\text { NS } \\
\text { NS }\end{array}$ & $\begin{array}{l}\text { NS } \\
\text { NS }\end{array}$ \\
\hline $\begin{array}{l}\text { R.K. } \\
\text { Saurenmann } \\
\text { et al. [4] }\end{array}$ & $\begin{array}{l}\text { NS } \\
\text { NS }\end{array}$ & NS & $\begin{array}{l}\text { Psoriatic JIA } \\
\text { Extended } \\
\text { oligoarticular } \\
\text { JIA }\end{array}$ & $\begin{array}{l}\text { NS } \\
\text { NS }\end{array}$ & $\begin{array}{l}\text { Etanercept } \\
\text { Etanercept }\end{array}$ & NS & NS & NS & NS \\
\hline $\begin{array}{l}\text { D. Wendling } \\
\text { et al. [5] }\end{array}$ & M & 5 & $\begin{array}{l}\text { NS } \\
\text { SA HLA-B27- }\end{array}$ & 3.5 & $\begin{array}{l}\text { Etanercept } \\
\text { Etanercept }\end{array}$ & 4 & $\begin{array}{l}\text { Anterior } \\
\text { bilateral } \\
\text { chronic } \\
\text { uveitis } \\
\text { Chronic } \\
\text { anterior } \\
\text { bilateral } \\
\text { uveitis }\end{array}$ & $\begin{array}{l}\text { Topical } \\
\text { corticosteroid } \\
\text { Topical } \\
\text { corticosteroid }\end{array}$ & $\begin{array}{l}\text { Switch to } \\
\text { infliximab } \\
\text { Switch to } \\
\text { infliximab }\end{array}$ \\
\hline $\begin{array}{l}\text { H. Schmeling } \\
\text { et al. [6] }\end{array}$ & F & $\begin{array}{l}17 \\
10\end{array}$ & $\begin{array}{l}\text { Polyarticular, } \\
\text { seronegative } \\
\text { Extended } \\
\text { oligoarticular }\end{array}$ & $\begin{array}{l}6.5 \\
5\end{array}$ & $\begin{array}{l}\text { Etanercept } \\
\text { Etanercept }\end{array}$ & $\begin{array}{l}10 \\
12\end{array}$ & $\begin{array}{l}\text { NS } \\
\text { NS }\end{array}$ & $\begin{array}{l}\text { NS } \\
\text { NS }\end{array}$ & $\begin{array}{l}\text { NS } \\
\text { NS }\end{array}$ \\
\hline $\begin{array}{l}\text { R. Scrivo et } \\
\text { al. [7] }\end{array}$ & $F$ & 16 & NS & 8 & Etanercept & 28 & $\begin{array}{l}\text { Anterior } \\
\text { uveitis }\end{array}$ & $\begin{array}{l}\text { Topical } \\
\text { corticosteroid }\end{array}$ & $\begin{array}{l}\text { Switch to } \\
\text { infliximab }\end{array}$ \\
\hline
\end{tabular}

Abbreviations: NS, not specified; JIA, juvenile idiopathic arthritis; SA, spondyloarthritis; $F$, female; $M$, male

Table 1: Cases of onset uveitis under TNF blockers

All these JIA cases were treated with etanercept.

The reason for the difference between the various TNF inhibitors and the risk of developing uveitis 
is unknown. In fact, the link between etanercept and uveitis is quite complex and there are many controversies. Some observations suggest that etanercept is not involved in generating uveitis. Schmeling and Horneff [6] reported a cohort of $229 \mathrm{JIA}$ patients treated with etanercept. Of this cohort, only two patients developed new-onset uveitis after initiation of etanercept, whereas several others experienced a flare of their previously diagnosed uveitis. Despite this, the authors concluded that etanercept treatment did not influence the incidence and course of JIA-related uveitis.

Furthermore, some clinicians believe that etanercept may trigger uveitis in a susceptible patient, despite its efficacy in treating joint diseases. Scrivo reported a cohort of 350 patients treated with etanercept, in whom new-onset anterior uveitis occurred in four, including one with JIA[7]. The authors suggested that monoclonal anti-TNF treatment, especially adalimumab[8], is preferable to the soluble TNF receptor agent in patients experiencing recurrent uveitis flares. Uveitis onset may be considered as a paradoxical effect of anti-TNF therapy, so called because it appeared after the initiation of the anti-TNF drugs that are normally used to treat it. In the majority of the cases in the literature, uveitis appeared at a time during which rheumatic disease manifestations were fully controlled, but in our patient the uveitis occurred during a JIA flare. The uveitis onset occurred after an average duration of exposure to etanercept of 12.5 months (US registry) [9]. Our case is original since uveitis appears after the first injection and it was a panuveitis, suggesting that etanercept had a role in the onset of uveitis.

Treatment of new-onset uveitis under anti-TNF was local in most of the cases, with healing of the episode within 2 months. Discontinuation of anti-TNF could be necessary in some cases. In the US registry[9], four cases of uveitis under etanercept resolved after discontinuing the medication, with a recurrence of uveitis on rechallenge in two of these patients. In our case, uveitis resolved under oral corticosteroids and when etanercept was switched to infliximab. Adalimumab is considered the most effective anti-TNF in the treatment of uveitis associated with oligo- and polyarticular JIAs, but could not be afforded in our case and infliximab proved to be successful.

\section{Learning points:}

- Paradoxical uveitis can occur early after the initiation of etanercept.

- Consider bilateral panuveitis, which is, to our knowledge, the first case described as a paradoxical effect of TNF $\alpha$ blockers.

- Further randomized controlled clinical trials are necessary to investigate possible immune reactions associated with etanercept. 


\section{European Journal \\ of Case Reports in \\ Internal Medicine}

\section{REFERENCES}

1. Kakkassery V, Mergler S, Pleyer U. Anti-TNF-alpha treatment: a possible promoter in endogenous uveitis? Observational report on six patients: occurrence of uveitis following etanercept treatment, Curr Eye Res 2010;35:751-756

2. Kaipiainen-Seppänen $O$, Leino $M$. Recurrent uveitis in a patient with juvenile spondyloarthropathy associated with tumour necrosis factor alpha inhibitors. Ann Rheum Dis 2003;62:88-89

3. Martín-Mola E, Sieper J, Leirisalo-Repo M, Dijkmans BA, Vlahos B, Pedersen R et al. Sustained efficacy and safety, including patient-reported outcomes, with etanercept treatment over 5 years in patients with ankylosing spondylitis, Clin. Exp. Rheumatol. 2010;28:238-245.

4. Saurenmann RK, Levin AV, Feldman BM, Laxer RM, Schneider R, Silverman ED. Risk of new-onset uveitis in patients with juvenile idiopathic arthritis treated with anti-TNF alpha agents, J. Pediatr. 2006;149:833-836.

5. Wendling D, Paccou J, Berthelot JM, Flipo RM, Guillaume-Czitrom S, Prati C, Dernis et al. New onset of uveitis during anti-tumor necrosis factor treatment for rheumatic diseases, Semin. Arthritis Rheum. 2011;41:503-510.

6. Schmeling $\mathrm{H}$, Horneff $\mathrm{G}$. Etanercept and uveitis in patients with juvenile idiopathic arthritis, Rheumatology (Oxford) 2005;44:1008-1011.

7. Scrivo R, Spadaro A, Spinelli FR, Valesini G. Uveitis following the use of tumor necrosis factor alpha inhibitors: comment on the article by Lim et al, Arthritis Rheum. 2008;58:1555-1556.

8. Anink J, Otten MH, Gorter SL et al. Treatment choices of paediatric rheumatologists for juvenile idiopathic arthritis: etanercept or adalimumab? Rheumatology (Oxford) 2013;52:1674.

9. Lim LL, Fraunfelder FW, Rosenbaum JT. Do tumor necrosis factor inhibitors cause uveitis? A registry-based study, Arthritis Rheum 2007;56:3248-3252. 